\title{
Hydrogenation of carbon dioxide to light olefins over non-supported iron catalyst
}

\author{
YOU Zhenya, DENG Weiping, ZHANG Qinghong, WANG Ye* \\ State Key Laboratory of Physical Chemistry of Solid Surfaces, National Engineering Laboratory for Green Chemical Production of Alcohols, Ethers, and \\ Esters, College of Chemistry and Chemical Engineering, Xiamen University, Xiamen 361005, Fujian, China
}

A R T I C L E I N F O

Article history:

Received 12 January 2013

Accepted 21 February 2013

Published 20 May 2013

\section{Keywords:}

Carbon dioxide

Hydrogenation

Light olefin

Iron catalyst

\begin{abstract}
A B S T R A C T
The hydrogenation of $\mathrm{CO}_{2}$ to light olefins was investigated over non-supported Fe catalysts. It was found that the addition of alkali metal ions to the Fe catalyst led to significant increases in both the $\mathrm{CO}_{2}$ conversion and the selectivity for olefins. Over $\mathrm{K}$ - or Rb-modified catalysts, about $40 \% \mathrm{CO}_{2}$ conversion and more than $50 \%$ olefin selectivity were obtained. The yield of $\mathrm{C}_{2}-\mathrm{C}_{4}$ olefins exceeded $10 \%$ over these modified catalysts. Catalyst characterization suggested that the formation of iron carbide species was accelerated by the modification of the Fe catalyst with alkali metal ions, and this enhancement may be one of the key reasons for the enhanced catalytic performance. For the $\mathrm{K}$-modified Fe catalysts, $\mathrm{K}$ content has a major influence on the catalyst behavior. An increase in the $\mathrm{K}$ content from 1 to $5 \mathrm{wt} \%$ increased both $\mathrm{CO}_{2}$ conversion and olefin selectivity. However, too high a $\mathrm{K}$ content led to a decrease in the activity, probably because of decreases in the surface area and $\mathrm{CO}_{2}$ chemisorption capacity of the catalyst. The presence of an appropriate amount of B in the K-modified Fe catalyst was found to be beneficial to the olefin selectivity, without significantly decreasing the conversion of $\mathrm{CO}_{2}$.
\end{abstract}

(c) 2013, Dalian Institute of Chemical Physics, Chinese Academy of Sciences. Published by Elsevier B.V. All rights reserved.

\section{Introduction}

The use of $\mathrm{CO}_{2}$ as a carbon resource for the production of fuels and chemicals not only contributes to the alleviation of global climate changes caused by growing $\mathrm{CO}_{2}$ emissions, but also provides an attractive approach to reducing dependence on fossil fuel resources. Recently, many studies have been devoted to the catalytic conversion of $\mathrm{CO}_{2}$ to hydrocarbons and oxygenates [1-8]. One promising route for the use of $\mathrm{CO}_{2}$ is the selective production of light olefins by the hydrogenation of $\mathrm{CO}_{2}$ with $\mathrm{H}_{2}$ [9]. Generally, the hydrogenation of $\mathrm{CO}_{2}$ by $\mathrm{H}_{2}$ to hydrocarbons proceeds via two steps, i.e., the reduction of $\mathrm{CO}_{2}$ to $\mathrm{CO}$ via the reverse water-gas shift (RWGS) reaction and sub- sequent CO hydrogenation, which is known as Fischer-Tropsch (FT) synthesis [10-12]. As efficient catalysts for both the RWGS reaction and FT synthesis $[13,14]$, Fe-based catalysts have received much attention for the hydrogenation of $\mathrm{CO}_{2}$ [15-20]. However, Fe catalysts alone are not suitable for FT synthesis as they produce undesired $\mathrm{CH}_{4}$ as the main product, and rapid deactivation of the catalysts also occurs easily [13,14]. Many studies have therefore focused on supported Fe catalysts modified with electronic and/or structural promoters to enhance the catalytic activity and product selectivity. For example, a K-modified $\mathrm{Fe} / \mathrm{Al}_{2} \mathrm{O}_{3}$ catalyst has been reported to provide $\mathrm{CO}_{2}$ conversion of $69 \%$ and a $\mathrm{C}_{2}-\mathrm{C}_{4}$ olefin selectivity of $40 \%$, with $\mathrm{CH}_{4}$ selectivity of less than $20 \%$, at $673 \mathrm{~K}$ [15]. Other additives,

\footnotetext{
*Corresponding author. Tel: +86-592-2186156; Fax: +86-592-2183047; E-mail: wangye@xmu.edu.cn

This work was supported by the National Basic Research Program of China (973 Program, 2013CB933100), the National Natural Science Foundation of China (21173174, 20923004, 21033006, and 21161130522), the Specialized Research Fund for the Doctoral Program of Higher Education (20090121110007), and the Program for Innovative Research Team in University (IRT1036).
} 
e.g., $\mathrm{Ce}, \mathrm{Mn}$, and $\mathrm{Cu}$, could also be used as promoters for $\mathrm{Fe} / \mathrm{Al}_{2} \mathrm{O}_{3}$ or $\mathrm{Fe} /$ silicate- 2 catalysts, which enhanced both $\mathrm{CO}_{2}$ conversion and $\mathrm{C}_{2+}$ olefin selectivity [16-20].

To date, studies of non-supported Fe catalysts are scarce [21]. Fe is a relatively cheap metal, and it can be used as an industrial catalyst without a support. To simplify the catalytic system and to gain more straightforward information on the effects of promoters without the complication of the "support effect", we performed the hydrogenation of $\mathrm{CO}_{2}$ to olefins over non-supported Fe catalysts. In the present paper, we report the effects of the modification of Fe catalysts with alkali metal ions on the catalyst structure and catalytic performance.

\section{Experimental}

\subsection{Catalyst preparation}

The non-supported Fe catalyst was prepared by calcining ammonium ferric citrate, i.e., $\mathrm{Fe}\left(\mathrm{NH}_{4}\right)_{3}\left(\mathrm{C}_{6} \mathrm{H}_{5} \mathrm{O}_{7}\right)_{2}$, at $773 \mathrm{~K}$ for 5 h. The alkali-metal-ion-promoted $\mathrm{Fe}$ catalysts were prepared using ammonium ferric citrate and alkali metal nitrates as precursors. In brief, the required amounts of ammonium ferric citrate and alkali metal nitrate were dissolved in deionized water and stirred vigorously at room temperature for $6 \mathrm{~h}$. Water was then evaporated from the mixed aqueous solution at $353 \mathrm{~K}$ with continuous stirring. The dried sample was calcined at $773 \mathrm{~K}$ in air for $5 \mathrm{~h}$. B-modified catalysts were prepared using the same procedure, except for the addition of boric acid $\left(\mathrm{H}_{3} \mathrm{BO}_{3}\right)$ to the mixed aqueous solution of alkali metal nitrate and ammonium ferric citrate.

\subsection{Catalyst characterization}

Powder X-ray diffraction (XRD) patterns were recorded using a Rigaku Altima IV diffractometer with $\mathrm{Cu} K_{\alpha}$ radiation (35 $\mathrm{kV}, 15 \mathrm{~mA}$ ). The specific surface area of catalysts was measured by $\mathrm{N}_{2}$ adsorption using a Micromeritics Tristar II 3020 instrument. Transmission electron microscopy (TEM) measurements were performed using a Tecnai F30 microscope at a voltage of $200 \mathrm{kV}$ for all catalysts. The mean size of Fe (or iron oxide) particles was estimated from the TEM micrographs by counting ca. 100-200 particles. X-ray photoelectron spectroscopy (XPS) measurements were carried out with a Quantum 2000 Scanning ESCA Microprobe instrument using $\mathrm{Al} K_{\alpha}$ radiation. The binding energy was calibrated using the $\mathrm{C} 1 \mathrm{~s}$ photoelectron peak at $284.8 \mathrm{eV}$ as a reference.

$\mathrm{CO}_{2}$ chemisorption measurements were performed at $323 \mathrm{~K}$ using a Micromeritics ASAP 2020 instrument. The sample $(0.10$ g) used for the chemisorption study was reduced at $673 \mathrm{~K}$ in an $\mathrm{H}_{2}$ gas flow, followed by evacuation at the reduction temperature and then cooling to $323 \mathrm{~K}$. The difference between the adsorption isotherms obtained by repeated use of a gas dosing and degassing system provided the amount of $\mathrm{CO}_{2}$ chemisorbed on the catalyst.

\subsection{Catalytic reaction}

The hydrogenation of $\mathrm{CO}_{2}$ was performed on a fixed-bed high-pressure stainless-steel reactor. The catalyst loaded in the reactor was first pretreated in an $\mathrm{H}_{2}$ gas flow (50 $\left.\mathrm{ml} / \mathrm{min}\right)$ at $673 \mathrm{~K}$ for $5 \mathrm{~h}$ prior to reaction. After the reactor was cooled to $353 \mathrm{~K}$, a mixture of $\mathrm{H}_{2} / \mathrm{CO}_{2} / \mathrm{Ar}$ with a molar ratio composition of 69/23/8 was introduced into the reactor. The pressure was typically regulated to $2.0 \mathrm{MPa}$. The reaction was started by raising the temperature to the desired reaction temperature (typically $613 \mathrm{~K}$ ). The products were analyzed using gas chromatography, and the results after $10 \mathrm{~h}$ of reaction were typically used for discussion.

\section{Results and discussion}

\subsection{Catalytic performance of non-supported Fe catalysts}

Table 1 shows the catalytic performance of Fe and alkali-metal-ion-modified Fe catalysts for the hydrogenation of $\mathrm{CO}_{2}$. The Fe catalyst without modification exhibited very low activity

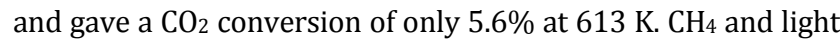
$\left(\mathrm{C}_{2}-\mathrm{C}_{4}\right)$ paraffins were the predominant products and no olefins were formed over the unmodified Fe catalyst. The modification of the Fe catalyst with an alkali metal ion significantly enhanced the catalytic performance for $\mathrm{CO}_{2}$ hydrogenation. For example, the $\mathrm{CO}_{2}$ conversion using an $\mathrm{Li}^{+}$-modified $\mathrm{Fe}$ catalyst was four times higher than that achieved using the unmodified catalyst. The selectivity for $\mathrm{CH}_{4}$ decreased significantly from $62 \%$ to $29 \%$, and olefins were formed with a selectivity of about $35 \%$ in the hydrocarbon products. Over $\mathrm{K}^{+-}$or $\mathrm{Rb}^{+}$-modified $\mathrm{Fe}$ catalysts, the conversion of $\mathrm{CO}_{2}$ and the olefin selectivity further increased to about $40 \%$ and $50 \%$, respectively. The yield of light $\left(\mathrm{C}_{2}-\mathrm{C}_{4}\right)$ olefins reached $10 \%-12 \%$. The alkali metal ion therefore not only greatly promoted the con-

Table 1

Effects of various alkali metal ion modifiers on catalytic performance of Fe catalysts for hydrogenation of $\mathrm{CO}_{2}$.

\begin{tabular}{|c|c|c|c|c|c|c|c|c|c|c|}
\hline \multirow{2}{*}{ Modifier } & \multirow{2}{*}{$\begin{array}{c}\mathrm{CO}_{2} \text { conversion } \\
(\%)\end{array}$} & \multicolumn{3}{|c|}{ Selectivity a (\%) } & \multicolumn{5}{|c|}{ Hydrocarbon distribution ${ }^{\mathrm{b}}(\%)$} & \multirow{2}{*}{$\begin{array}{c}\mathrm{C}_{2-4}=\text { yield } \\
(\%)\end{array}$} \\
\hline & & $\mathrm{CO}$ & $\mathrm{HC}$ & C-oxy & $\mathrm{CH}_{4}$ & $\mathrm{C}_{2-4}=$ & $\mathrm{C}_{2-4^{0}}$ & $\mathrm{C}_{5+}=$ & $\mathrm{C}_{5+}{ }^{0}$ & \\
\hline None & 5.6 & 12 & 89 & 0.0 & 62 & 0.0 & 38 & 0.0 & 0.9 & 0.0 \\
\hline $\mathrm{Li}^{+}$ & 27 & 17 & 73 & 10 & 29 & 30 & 30 & 4.8 & 5.5 & 5.8 \\
\hline $\mathrm{Na}^{+}$ & 24 & 21 & 68 & 11 & 30 & 36 & 24 & 5.6 & 4.0 & 5.9 \\
\hline $\mathrm{K}^{+}$ & 38 & 7.3 & 78 & 15 & 21 & 34 & 14 & 19 & 11 & 10 \\
\hline $\mathrm{Rb}^{+}$ & 42 & 5.9 & 77 & 17 & 27 & 37 & 17 & 12 & 6.1 & 12 \\
\hline $\mathrm{Cs}^{+}$ & 39 & 6.6 & 90 & 3.9 & 28 & 24 & 31 & 8.6 & 7.4 & 8.6 \\
\hline
\end{tabular}

Reaction conditions: catalyst (alkali metal content $=5 \mathrm{wt} \%$ ), $1.0 \mathrm{~g} ; F=20 \mathrm{ml} / \mathrm{min} ; \mathrm{H}_{2} / \mathrm{CO}_{2}=3 ; p=2 \mathrm{MPa} ; T=613 \mathrm{~K} ; t=10 \mathrm{~h}$. ${ }^{a} \mathrm{HC}$ and C-oxy denote hydrocarbons and organic oxygenates, respectively.

${ }^{\mathrm{b}} \mathrm{C}_{2-4}=$ and $\mathrm{C}_{2-4}{ }^{0}$ denote $\mathrm{C}_{2}-\mathrm{C}_{4}$ olefins and paraffins, respectively, while $\mathrm{C}_{5+}{ }^{=}$and $\mathrm{C}_{5+}{ }^{0}$ denote $\mathrm{C}_{5+}$ olefins and paraffins, respectively. 
version of $\mathrm{CO}_{2}$ but also significantly changed the product distributions in the hydrogenation of $\mathrm{CO}_{2}$. The selectivities for $\mathrm{CH}_{4}$ and $\mathrm{C}_{2}-\mathrm{C}_{4}$ paraffins were suppressed, whereas olefin selectivity, particularly $\mathrm{C}_{2}-\mathrm{C}_{4}$ olefins, was significantly enhanced. The yield of $\mathrm{C}_{2}-\mathrm{C}_{4}$ olefins increased in the following order: $\mathrm{Fe}<$ $\mathrm{Li}^{+}$-modified $\mathrm{Fe}<\mathrm{Na}^{+}$-modified $\mathrm{Fe}<\mathrm{Cs}^{+}$-modified $\mathrm{Fe}<$ $\mathrm{K}^{+}$-modified $\mathrm{Fe}<\mathrm{Rb}^{+}$-modified $\mathrm{Fe}$. In other words, a catalyst modified with an alkali metal ion with a stronger basicity exhibits a more significant promoting effect for the hydrogenation of $\mathrm{CO}_{2}$ to light olefins, except for the $\mathrm{Cs}^{+}$-modified catalyst. To the best of our knowledge, this is the first report to demonstrate that considerable $\mathrm{C}_{2}-\mathrm{C}_{4}$ olefin yields can be achieved by simply modifying an Fe catalyst with an alkali metal ion.

Although the $\mathrm{Rb}^{+}$-modified catalyst gave the best yield of $\mathrm{C}_{2}-\mathrm{C}_{4}$ olefins, the $\mathrm{K}^{+}$-modified $\mathrm{Fe}$ catalyst was also efficient and was much cheaper than the $\mathrm{Rb}^{+}$-modified catalyst. We therefore further investigated the effect of the $\mathrm{K}$ content on the catalytic performance of the $\mathrm{K}^{+}$-modified Fe catalysts for the hydrogenation of $\mathrm{CO}_{2}$. Table 2 shows that, with increasing $\mathrm{K}$ content up to $5 \mathrm{wt} \%$, the conversion of $\mathrm{CO}_{2}$ and the olefin selectivity increased rapidly, and the $\mathrm{CH}_{4}$ selectivity decreased sharply. The highest $\mathrm{C}_{2}-\mathrm{C}_{4}$ olefin yield was achieved over the catalyst with a $\mathrm{K}$ content of 5-10 wt\%. Further increases in the $\mathrm{K}$ content led to decreases in the conversion of $\mathrm{CO}_{2}$ and yield of $\mathrm{C}_{2}-\mathrm{C}_{4}$ olefins. An appropriate $\mathrm{K} / \mathrm{Fe}$ ratio was required to obtain high olefin yields from $\mathrm{CO}_{2}$ hydrogenation.

We found that the catalytic performance, particularly the $\mathrm{C}_{2}-\mathrm{C}_{4}$ olefin selectivity, could be further promoted to some extent by B-doping of the Fe catalyst modified with $5 \mathrm{wt} \% \mathrm{~K}^{+}$. As shown in Table 3, the addition of a small amount of $\mathrm{B}(\leq 1.0$ $\mathrm{wt} \%$ ) to the $5-\mathrm{wt} \%-\mathrm{K}^{+}$-modified Fe catalyst did not change, or slightly increased, the conversion of $\mathrm{CO}_{2}$. However, as the content of $\mathrm{B}$ increased to $\geq 3 \mathrm{wt} \%$, significant decreases in $\mathrm{CO}_{2}$ conversion were observed. The interesting point is that modi- fication with $\mathrm{B}$ can modify the product distribution. In particular, with increasing B content from $0.5 \mathrm{wt} \%$ to $5.0 \mathrm{wt} \%$, the selectivity for $\mathrm{C}_{2}-\mathrm{C}_{4}$ olefins increased from $34 \%$ to $52 \%$. The $\mathrm{C}_{2}-\mathrm{C}_{4}$ olefin selectivity and yield were $40 \%$ and $12 \%$, respectively, over the $1.0 \mathrm{wt} \% \mathrm{~B}-5.0 \mathrm{wt} \% \mathrm{~K}^{+}-\mathrm{Fe}$ catalyst. However, when the content of $\mathrm{B}$ rose to $\geq 3.0 \%$, the CO selectivity increased from $<10 \%$ to $19 \%-28 \%$, and that for hydrocarbons decreased to $65 \%-75 \%$. Because of this and the decrease in $\mathrm{CO}_{2}$ conversion, catalysts with higher $\mathrm{B}$ contents $(>1 \mathrm{wt} \%)$ did not give higher yields of $\mathrm{C}_{2}-\mathrm{C}_{4}$ olefins. In spite of this, modification with an appropriate amount of B (1.0-5.0 wt\%) decreased the selectivity for $\mathrm{C}_{5}$ hydrocarbons and increased that for $\mathrm{C}_{2}-\mathrm{C}_{4}$ olefins, without increasing that for $\mathrm{CH}_{4}$.

\subsection{Characterization of non-supported Fe catalysts}

Figure 1 shows the XRD patterns of the Fe catalysts with and without alkali metal ion modifications. Analyses of the diffraction patterns in Fig. 1(a) reveal that magnetite $\left(\mathrm{Fe}_{3} \mathrm{O}_{4}\right)$ and hematite $\left(\mathrm{Fe}_{2} \mathrm{O}_{3}\right)$ co-exist in all of the fresh catalysts. The relatively strong intensities of the XRD peaks ascribed to $\mathrm{Fe}_{3} \mathrm{O}_{4}$ suggest that $\mathrm{Fe}_{3} \mathrm{O}_{4}$ is the main crystalline phase in all the alkali-metal-ion-modified Fe catalysts. The diffraction peaks of $\mathrm{Fe}_{3} \mathrm{O}_{4}$ and $\mathrm{Fe}_{2} \mathrm{O}_{3}$ for the unmodified $\mathrm{Fe}$ catalyst were narrower and sharper than those for the Fe catalysts modified with alkali metal ions (Fig. 1(a)). This indicates decreases in the sizes of the $\mathrm{Fe}_{3} \mathrm{O}_{4}$ and $\mathrm{Fe}_{2} \mathrm{O}_{3}$ crystallites after modification with alkali metal ions. We calculated the size of the $\mathrm{Fe}_{3} \mathrm{O}_{4}$ crystallites from the Scherrer equation using the (311) facet of $\mathrm{Fe}_{3} \mathrm{O}_{4}$. The results showed that the size of the $\mathrm{Fe}_{3} \mathrm{O}_{4}$ crystallites in the 5-wt\%-K+-modified Fe catalyst was about $17 \mathrm{~nm}$, smaller than that $(27 \mathrm{~nm})$ in the unmodified Fe catalyst. No diffraction peaks corresponding to alkali metal compounds were detected in the $\mathrm{XRD}$ patterns. It is probable that the alkali metal ions are highly

Table 2

Catalytic performance of $\mathrm{K}^{+}$-modified $\mathrm{Fe}$ catalysts with different $\mathrm{K}$ contents for hydrogenation of $\mathrm{CO}_{2}$.

\begin{tabular}{|c|c|c|c|c|c|c|c|c|c|c|}
\hline \multirow{2}{*}{$\begin{array}{l}\text { Kcontent } \\
\text { (wt\%) }\end{array}$} & \multirow{2}{*}{$\begin{array}{c}\mathrm{CO}_{2} \text { conversion } \\
(\%)\end{array}$} & \multicolumn{3}{|c|}{ Selectivity (\%) } & \multicolumn{5}{|c|}{ Hydrocarbon distribution (\%) } & \multirow{2}{*}{$\begin{array}{c}\mathrm{C}_{2-4}=\text { yield } \\
(\%)\end{array}$} \\
\hline & & $\mathrm{CO}$ & $\mathrm{HC}$ & C-oxy & $\mathrm{CH}_{4}$ & $\mathrm{C}_{2-4}=$ & $\mathrm{C}_{2-4^{0}}$ & $\mathrm{C}_{5+}=$ & $\mathrm{C}_{5+}{ }^{0}$ & \\
\hline 0 & 5.6 & 12 & 88 & 0.0 & 62 & 0.0 & 38 & 0.0 & 0.9 & 0.0 \\
\hline 1.0 & 5.0 & 10 & 89 & 1.3 & 45 & 2.1 & 48 & 0.1 & 5.2 & 0.1 \\
\hline 2.0 & 37 & 5.8 & 86 & 7.8 & 28 & 25 & 34 & 6.8 & 3.4 & 7.9 \\
\hline 5.0 & 38 & 7.3 & 78 & 15 & 21 & 34 & 14 & 19 & 11 & 10 \\
\hline 10 & 27 & 7.2 & 89 & 4.3 & 22 & 39 & 13 & 18 & 7.2 & 9.3 \\
\hline 16 & 25 & 8.3 & 79 & 13 & 23 & 37 & 18 & 21 & 6.7 & 7.3 \\
\hline 32 & 25 & 20 & 71 & 9.6 & 24 & 36 & 11 & 22 & 6.5 & 6.3 \\
\hline
\end{tabular}

Reaction conditions: catalyst, $1.0 \mathrm{~g} ; F=20 \mathrm{ml} / \mathrm{min} ; \mathrm{H}_{2} / \mathrm{CO}_{2}=3 ; p=2 \mathrm{MPa} ; T=613 \mathrm{~K} ; t=10 \mathrm{~h}$.

Table 3

Effect of B modification on catalytic performance of 5-wt\%-K+-modified Fe catalysts.

\begin{tabular}{|c|c|c|c|c|c|c|c|c|c|c|}
\hline \multirow{2}{*}{$\begin{array}{l}\text { B content } \\
(w \mathrm{t} \%)\end{array}$} & \multirow{2}{*}{$\begin{array}{c}\mathrm{CO}_{2} \text { conversion } \\
(\%)\end{array}$} & \multicolumn{3}{|c|}{ Selectivity (\%) } & \multicolumn{5}{|c|}{ Hydrocarbon distribution (\%) } & \multirow{2}{*}{$\begin{array}{c}\mathrm{C}_{2-4}=\text { yield } \\
(\%)\end{array}$} \\
\hline & & $\mathrm{CO}$ & $\mathrm{HC}$ & C-oxy & $\mathrm{CH}_{4}$ & $\mathrm{C}_{2-4}=$ & $\mathrm{C}_{2-4}{ }^{0}$ & $\mathrm{C}_{5+}=$ & $\mathrm{C}_{5+}{ }^{0}$ & \\
\hline 0 & 38 & 7.3 & 78 & 15 & 21 & 34 & 14 & 19 & 11 & 10 \\
\hline 0.5 & 43 & 6.4 & 81 & 13 & 22 & 34 & 18 & 13 & 12 & 12 \\
\hline 1.0 & 38 & 7.6 & 79 & 13 & 23 & 40 & 18 & 10 & 8.6 & 12 \\
\hline 3.0 & 25 & 26 & 68 & 6.8 & 19 & 52 & 17 & 8.1 & 3.9 & 8.8 \\
\hline 5.0 & 23 & 29 & 65 & 5.8 & 19 & 52 & 20 & 6.9 & 3.0 & 7.6 \\
\hline 6.0 & 22 & 19 & 74 & 6.9 & 36 & 33 & 25 & 3.4 & 3.0 & 5.3 \\
\hline 8.0 & 21 & 21 & 75 & 4.7 & 51 & 19 & 27 & 1.2 & 1.9 & 3.0 \\
\hline
\end{tabular}

Reaction conditions: catalyst (B- and $\mathrm{K}^{+}$-modified Fe), $1.0 \mathrm{~g} ; F=20 \mathrm{ml} / \mathrm{min} ; \mathrm{H}_{2} / \mathrm{CO}_{2}=3 ; p=2 \mathrm{MPa} ; T=613 \mathrm{~K} ; t=10 \mathrm{~h}$. 


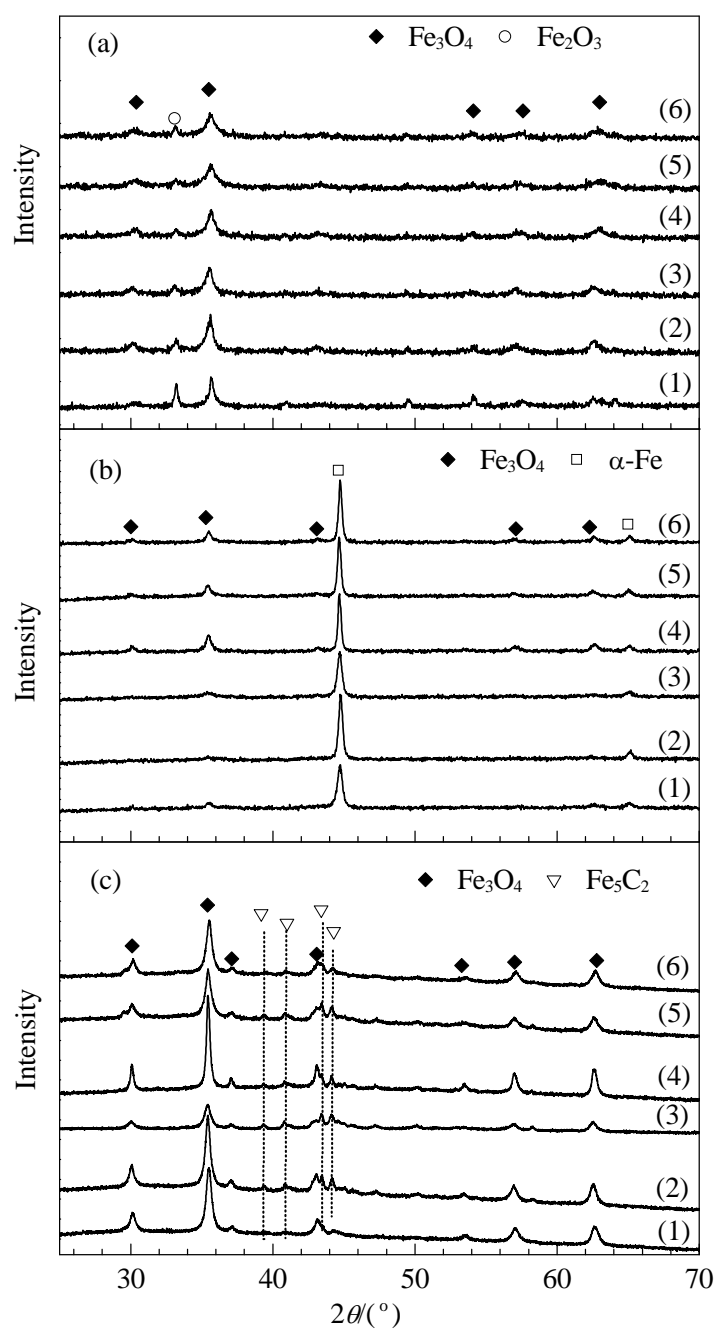

Fig. 1. XRD patterns of Fe catalysts with and without alkali metal ion modifications. (a) Before reaction; (b) After reductive treatment in $\mathrm{H}_{2}$ at $673 \mathrm{~K}$; (c) After $10 \mathrm{~h}$ of reaction under the following conditions: $\mathrm{H}_{2} / \mathrm{CO}_{2} / \mathrm{Ar}=69 / 23 / 8, p=2 \mathrm{MPa}, \mathrm{T}=613 \mathrm{~K}$. (1) Fe; (2) $5 \mathrm{wt} \% \mathrm{Li}-\mathrm{Fe} ;(3)$ 5 wt $\%$ Na-Fe; (4) 5 wt $\%$ K-Fe; (5) 5 wt $\%$ Rb-Fe; (6) 5 wt\% Cs-Fe.

dispersed in the modified catalysts and may interact with iron oxide particles, preventing the growth of iron oxide particles during calcination.

After reductive treatment in $\mathrm{H}_{2}$ at $673 \mathrm{~K}$, a key step for catalyst activation, all of the samples displayed diffraction peaks at $2 \theta$ values of $44.7^{\circ}$ and $65.0^{\circ}$, which could be ascribed to crystalline $\alpha$-Fe. The stronger intensity of the XRD peak at a $2 \theta$ value of $44.7^{\circ}$ suggests that $\alpha-F e$ is the major phase in all the catalysts (Fig. 1(b)). This indicates that a large part of the $\mathrm{Fe}_{3} \mathrm{O}_{4}$ and $\mathrm{Fe}_{2} \mathrm{O}_{3}$ in the fresh catalysts has been reduced to $\alpha-\mathrm{Fe}$ after reduction in $\mathrm{H}_{2}$ at $673 \mathrm{~K}$. However, some $\mathrm{Fe}_{3} \mathrm{O}_{4}$ was still detectable in the reductively treated catalysts.

After catalytic reaction for $10 \mathrm{~h}, \mathrm{Fe}_{3} \mathrm{O}_{4}$ became the major crystalline phase in all the catalysts (Fig. 1(c)). Moreover, new diffraction peaks at $2 \theta$ values of $44.2^{\circ}$ and $43.4^{\circ}$ were observed in the alkali-metal-ion-modified Fe catalysts. However, these peaks were not clearly observed in the used unmodified Fe catalyst. These peaks could be assigned to the (021) and (510) reflections of crystalline $\chi-\mathrm{Fe}_{5} \mathrm{C}_{2}$ [22]. This observation suggests that the alkali metal ions accelerate generation of the $\chi-\mathrm{Fe}_{5} \mathrm{C}_{2}$ phase in the catalysts after reaction.

The XRD patterns of $\mathrm{K}^{+}$-modified Fe catalysts with different $\mathrm{K}$ contents are displayed in Fig. 2. Only iron oxide (i.e., $\mathrm{Fe}_{3} \mathrm{O}_{4}$ and $\mathrm{Fe}_{2} \mathrm{O}_{3}$ ) phases were observed for all the fresh catalysts (Fig. 2(a)). No diffraction peaks of K-related compounds were detected using XRD, even for the catalyst with a very high $\mathrm{K}$ content (32 wt\%). Figure 2(b) shows that the content of $\mathrm{K}$ exerts little influence on the reduction of iron oxides to $\alpha$-Fe. After the catalytic reaction at $613 \mathrm{~K}$, the diffraction peaks attributed to the $\chi-\mathrm{Fe}_{5} \mathrm{C}_{2}$ phase appeared in all the K-modified $\mathrm{Fe}$ catalysts with different $\mathrm{K}$ contents (Fig. 2(c)). This is further evidence that $\mathrm{K}$ promotes formation of iron carbide species. A weak diffraction peak attributable to $\mathrm{K}_{2} \mathrm{O}$ was observed for the catalyst with a K content of $32 \mathrm{wt} \%$ (Fig. 2(c), curve (7)), and the intensities of the diffraction peaks of $\mathrm{Fe}_{3} \mathrm{O}_{4}$ decreased when the content of $\mathrm{K}$ increased to $32 \mathrm{wt} \%$.

The addition of $\mathrm{B}$ to the 5 -wt $\%$-K-modified Fe catalyst

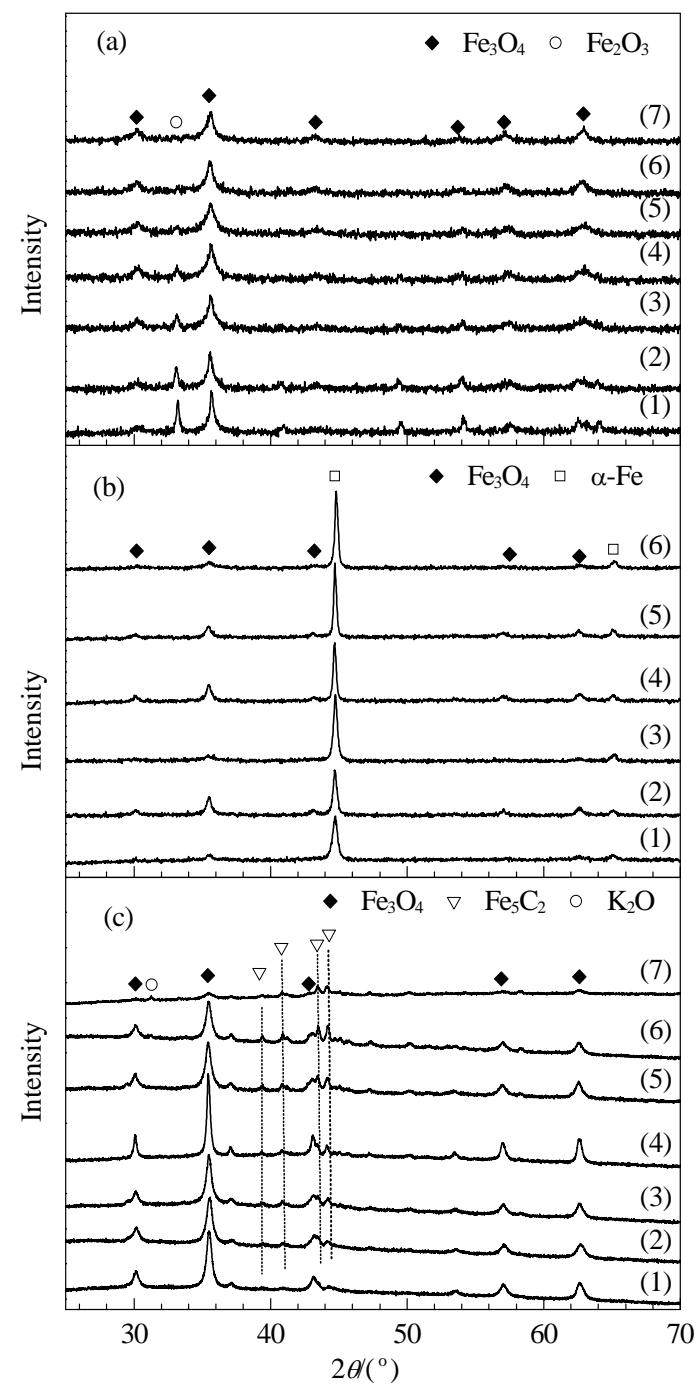

Fig. 2. XRD patterns of $\mathrm{K}^{+}$-modified Fe catalysts with different $\mathrm{K}^{+}$contents. (a) Before reaction; (b) After reductive treatment in $\mathrm{H}_{2}$ at $673 \mathrm{~K}$; (c) After $10 \mathrm{~h}$ of reaction under the following conditions: $\mathrm{H}_{2} / \mathrm{CO}_{2} / \mathrm{Ar}=$ $69 / 23 / 8, p=2 \mathrm{MPa} ; T=613 \mathrm{~K}$. (1) Fe; (2) 1 wt $\% \mathrm{~K}-\mathrm{Fe}$; (3) 2 wt $\% \mathrm{~K}-\mathrm{Fe}$; (4) 5 wt $\%$ K-Fe; (5) 10 wt\% K-Fe; (6) 16 wt\% K-Fe; (7) 32 wt $\%$ K-Fe. 
changed the XRD pattern. As shown in Fig. 3, all of the diffraction peaks ascribed to iron oxides were broadened by the presence of $\mathrm{B}$ in the $\mathrm{K}^{+}$-modified $\mathrm{Fe}$ catalyst. Moreover, the hematite $\left(\mathrm{Fe}_{2} \mathrm{O}_{3}\right)$ phase in the fresh catalyst disappeared immediately after the introduction of $\mathrm{B}$ into the $\mathrm{K}^{+}$-modified $\mathrm{Fe}$ catalyst, and only the magnetite $\left(\mathrm{Fe}_{3} \mathrm{O}_{4}\right)$ phase was detectable by XRD (Fig. 3(a)). Figure 3(b) shows that the ratio of the intensity of the strongest diffraction peak of $\alpha$-Fe to that of $\mathrm{Fe}_{3} \mathrm{O}_{4}$ decreases with increasing $\mathrm{B}$ content, implying that the reduction of $\mathrm{Fe}_{3} \mathrm{O}_{4}$ in a $\mathrm{H}_{2}$ flow at $673 \mathrm{~K}$ becomes more difficult in the presence of a $\mathrm{B}$ modifier. After the catalytic reactions, the formation of the $\chi-\mathrm{Fe}_{5} \mathrm{C}_{2}$ phase in the $\mathrm{B}$-modified samples was still clearly observed although the intensities of all the diffraction peaks were weaker (Fig. 3(c)).

Further investigations revealed that the surface area and the amount of $\mathrm{CO}_{2}$ chemisorption changed after modification of the Fe catalyst with $\mathrm{K}^{+}$and/or B. As shown in Table 4, although no

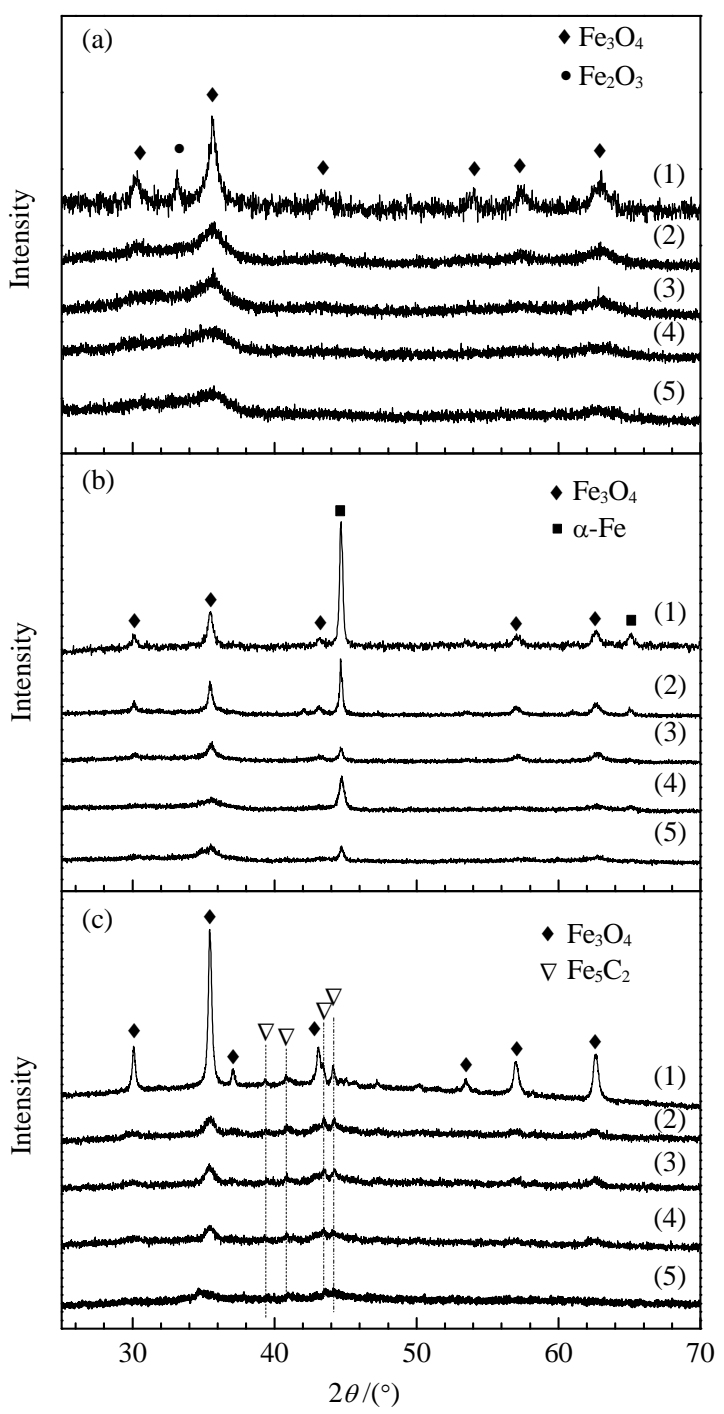

Fig. 3. XRD patterns of B-doped 5 wt $\% \mathrm{~K}$-Fe catalysts with different B contents. (a) Fresh catalyst; (b) After reductive treatment in $\mathrm{H}_{2}$ at 673 $\mathrm{K}$; (c) After $10 \mathrm{~h}$ of reaction under the following conditions: $\mathrm{H}_{2} / \mathrm{CO}_{2} / \mathrm{Ar}$ = 69/23/8, $p=2 \mathrm{MPa} ; \mathrm{T}=613 \mathrm{~K}$. (1) $5 \mathrm{wt} \% \mathrm{~K}-\mathrm{Fe}$; (2) $1 \mathrm{wt} \% \mathrm{~B}-5 \mathrm{wt} \%$ K-Fe; (3) 3 wt $\%$ B-5 wt $\%$ K-Fe; (4) 5 wt $\%$ B-5 wt $\%$ K-Fe; (5) 8 wt\% B-5 $\mathrm{wt} \% \mathrm{~K}-\mathrm{Fe}$.
Table 4

Surface areas and amounts of $\mathrm{CO}_{2}$ chemisorption for fresh Fe catalysts modified with different amounts of $\mathrm{K}$ and $\mathrm{B}$.

\begin{tabular}{lcc}
\hline Catalyst & $\begin{array}{c}\text { Surface area } \\
\left(\mathrm{m}^{2} / \mathrm{g}\right)\end{array}$ & $\begin{array}{c}\text { Amount of } \mathrm{CO}_{2} \text { chemisorption } \\
(\mu \mathrm{mol} / \mathrm{g})\end{array}$ \\
\hline $\mathrm{Fe}$ & 54 & 116 \\
$1 \mathrm{wt} \% \mathrm{~K}-\mathrm{Fe}$ & 67 & 116 \\
$5 \mathrm{wt} \% \mathrm{~K}-\mathrm{Fe}$ & 63 & 218 \\
$10 \mathrm{wt} \% \mathrm{~K}-\mathrm{Fe}$ & 54 & 126 \\
$16 \mathrm{wt} \% \mathrm{~K}-\mathrm{Fe}$ & 21 & 52 \\
$1 \mathrm{wt} \% \mathrm{~B}-5 \mathrm{wt} \% \mathrm{~K}-\mathrm{Fe}$ & 95 & 220 \\
$3 \mathrm{wt} \% \mathrm{~B}-5 \mathrm{wt} \% \mathrm{~K}-\mathrm{Fe}$ & 122 & 184 \\
$5 \mathrm{wt} \% \mathrm{~B}-5 \mathrm{wt} \% \mathrm{~K}-\mathrm{Fe}$ & 117 & 133 \\
$8 \mathrm{wt} \% \mathrm{~B}-5 \mathrm{wt} \% \mathrm{~K}-\mathrm{Fe}$ & 120 & 99 \\
\hline
\end{tabular}

support was used in our study, a specific surface area of 54 $\mathrm{m}^{2} / \mathrm{g}$ was attained for the non-modified Fe catalyst prepared by calcination of ammonium ferric citrate. Compared with the conventional precipitation method or the microemulsion technique for the preparation of Fe catalysts [21], this simple procedure is an effective way of obtaining non-supported Fe materials with relatively high surface area. After the addition of a low amount of $\mathrm{K}^{+}(1-5 \mathrm{wt} \%)$, the surface area of the catalyst is larger than that of the unmodified Fe catalyst. We speculate that a lower content of alkali metal ions may help to disperse iron oxides, thus avoiding the growth of iron oxide particles during calcination. This was supported by calculation of the crystallite size of $\mathrm{Fe}_{3} \mathrm{O}_{4}$ from the XRD patterns in Fig. 1(a). Furthermore, the TEM images shown in Fig. 4 confirm that the mean size of iron oxide particles decreased from $30.9 \mathrm{~nm}$ to $11.1 \mathrm{~nm}$ as a result of modification with $\mathrm{K}^{+}$. However, too high a $\mathrm{K}$ content led to a decrease in the surface area (Table 4). Recently, Dorner et al. [23] reported that $\mathrm{K}$ species could form a monomer layer on Fe surfaces when $8 \mathrm{wt} \% \mathrm{~K}$ was loaded on a 17 wt $\% \mathrm{Fe}-\mathrm{Mn} / \mathrm{Al}_{2} \mathrm{O}_{3}$ catalyst. Although $\mathrm{Al}_{2} \mathrm{O}_{3}$ was used as the support in their case, the $\mathrm{K}^{+}$was still found to cover the Fe surface preferentially. It is also interesting that the addition of $\mathrm{B}$ to the 5-wt\%-K-modified Fe catalyst significantly increased the surface area. The surface area rose to about $120 \mathrm{~m}^{2} / \mathrm{g}$ with increasing B content to $3 \mathrm{wt} \%$. A further increase in the B content did not change the surface area significantly. The mean size of the iron oxide particles in the $1 \mathrm{wt} \% \mathrm{~B}-5 \mathrm{wt} \%$ K-modified Fe catalyst was $11.0 \mathrm{~nm}$ (Fig. 4).

Table 4 also shows that the amount of $\mathrm{CO}_{2}$ chemisorption is significantly enhanced by the addition of 5-10 wt\% $\mathrm{K}^{+}$to the $\mathrm{Fe}$ catalyst. The degree of increase in the amount of $\mathrm{CO}_{2}$ chemisorption for the $5 \mathrm{wt} \% \mathrm{~K}^{+}$-modified catalyst was larger than that in the surface area. This is believed to be caused by increased surface basicity as a result of the introduction of $\mathrm{K}^{+}$in the catalyst. With further increases in the $\mathrm{K}^{+}$content, the amount of $\mathrm{CO}_{2}$ chemisorption decreased, probably because of a decrease in the surface area. For the B-K-Fe series of catalysts, the amount of $\mathrm{CO}_{2}$ chemisorption decreased with increasing $\mathrm{B}$ content. Generally, B has an acidic character, and thus the basicity of the $5-\mathrm{wt} \%-\mathrm{K}^{+}$-modified catalyst decreased on addition of acidic $B$.

Figure 5 shows the XPS spectra of the Fe catalysts modified with different amounts of $\mathrm{K}$ and $\mathrm{B}$. For all the catalysts modified with $\mathrm{K}^{+}$, the binding energies of $\mathrm{K} 2 p_{3 / 2}$ and $\mathrm{K} 2 p_{1 / 2}$ were locat- 

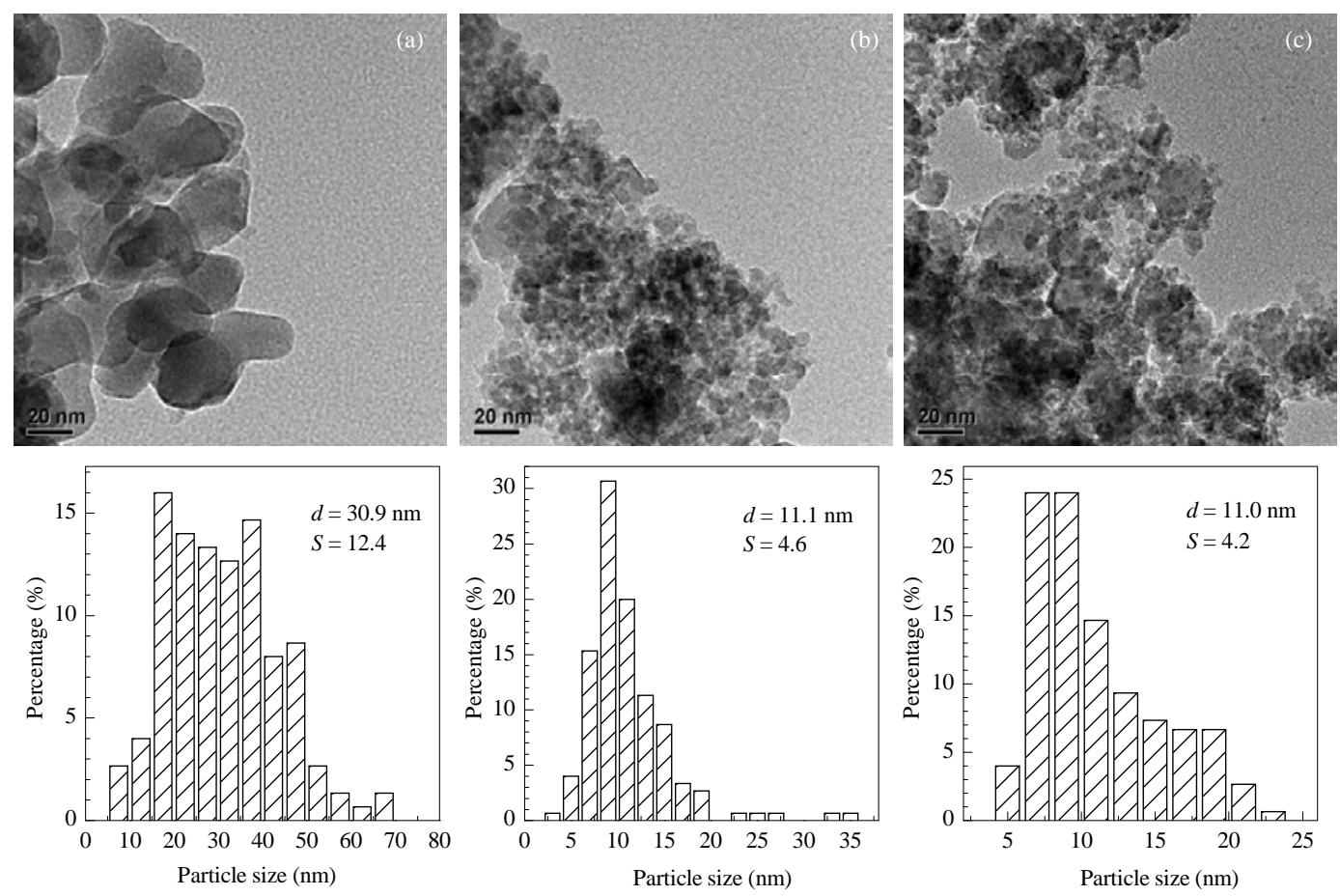

Fig. 4. TEM images and particle size distribution of Fe (a), $5 \mathrm{wt} \% \mathrm{~K}-\mathrm{Fe}(\mathrm{b})$, and $1 \mathrm{wt} \% \mathrm{~B}-5 \mathrm{wt} \% \mathrm{~K}-\mathrm{Fe}(\mathrm{c}) . d$ and $S$ denote mean size and standard deviation, respectively.
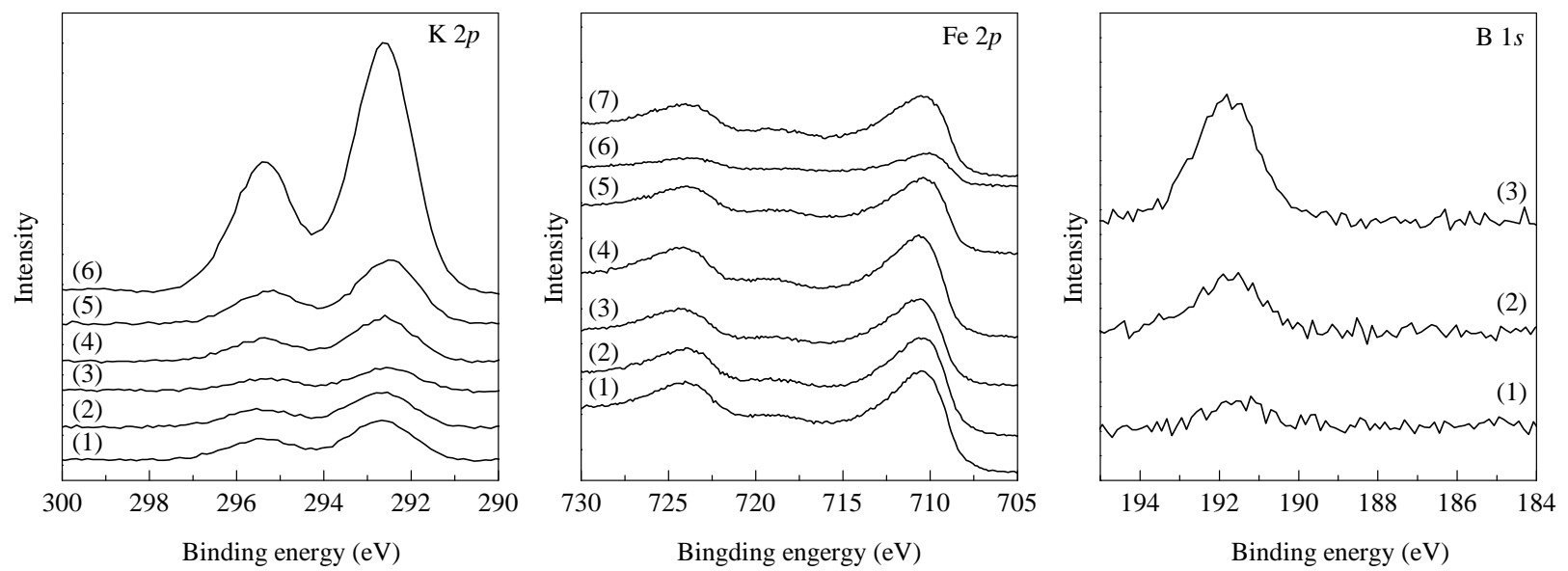

Fig. 5. XPS spectra of fresh Fe catalysts modified with different amounts of $\mathrm{K}^{+}$and B. (1) $1 \mathrm{wt} \% \mathrm{~B}-5 \mathrm{wt} \% \mathrm{~K}-\mathrm{Fe}$; (2) $3 \mathrm{wt} \% \mathrm{~B}-5 \mathrm{wt} \% \mathrm{~K}-\mathrm{Fe}$; (3) 8 wt $\%$ B-5 wt\% K-Fe; (4) 5 wt\% K-Fe; (5) 16 wt\% K-Fe; (6) 32 wt\% K-Fe; (7) Fe.

ed at $292.6 \mathrm{eV}$ and $295.4 \mathrm{eV}$, respectively, suggesting that $\mathrm{K}_{2} \mathrm{O}$ was the dominant $\mathrm{K}$ species on the catalyst surfaces. We calculated the $\mathrm{K} / \mathrm{Fe}$ atomic ratios for the K-Fe catalysts using the XPS results (Table 5). Over the catalysts with 5-16 wt\% K, the surface and bulk $\mathrm{K} / \mathrm{Fe}$ ratios were very close. However, as the $\mathrm{K}$ content increased to $32 \mathrm{wt} \%$, the $\mathrm{K} / \mathrm{Fe}$ ratio on the surface reached 2.0 and became significantly larger than that in the bulk (0.67). This indicates that the catalyst surface is covered by excess $\mathrm{K}_{2} \mathrm{O}$; this is in agreement with the XRD observations (Fig. 2).

It is also clear that the introduction of B into the K-Fe catalyst does not change the oxidation states of $\mathrm{K}$ and Fe (Fig. 5). The peak at a binding energy of $191.8 \mathrm{eV}$, for $\mathrm{B} 1 s$, which is assignable to $\mathrm{B}_{2} \mathrm{O}_{3}$ [24], can be detected for all the B-doped catalysts. Comparison of the $\mathrm{B} / \mathrm{Fe}$ and $\mathrm{K} / \mathrm{Fe}$ ratios for the $\mathrm{B}-\mathrm{K}-\mathrm{Fe}$ catalysts clearly suggests that the B species are preferentially located in the bulk of the catalyst, irrespective of the amount of

Table 5

Atomic ratios of $\mathrm{K} / \mathrm{Fe}$ and $\mathrm{B} / \mathrm{Fe}$ for fresh $\mathrm{Fe}$ catalysts modified with different amounts of $\mathrm{K}$ and $\mathrm{B}$.

\begin{tabular}{lccccc}
\hline \multirow{2}{*}{ Catalyst } & \multicolumn{2}{c}{ K/Fe atomic ratio } & & \multicolumn{2}{c}{ B/Fe atomic ratio } \\
\cline { 2 - 3 } \cline { 5 - 6 } Calculated & Measured & & Calculated $^{\mathrm{a}}$ & Measured $^{\mathrm{b}}$ \\
\hline $5 \mathrm{wt} \% \mathrm{~K}-\mathrm{Fe}$ & 0.075 & 0.090 & & - & - \\
$16 \mathrm{wt} \% \mathrm{~K}-\mathrm{Fe}$ & 0.27 & 0.24 & & - & - \\
$32 \mathrm{wt} \% \mathrm{~K}-\mathrm{Fe}$ & 0.67 & 2.0 & & - & - \\
$1 \mathrm{wt} \% \mathrm{~B}-5 \mathrm{wt} \% \mathrm{~K}-\mathrm{Fe}$ & 0.076 & 0.072 & & 0.055 & 0.041 \\
$3 \mathrm{wt} \% \mathrm{~B}-5 \mathrm{wt} \% \mathrm{~K}-\mathrm{Fe}$ & 0.078 & 0.083 & & 0.17 & 0.13 \\
$8 \mathrm{wt} \% \mathrm{~B}-5 \mathrm{wt} \% \mathrm{~K}-\mathrm{Fe}$ & 0.082 & 0.067 & & 0.48 & 0.34 \\
\hline
\end{tabular}

a Calculated from the amounts of materials used for preparation.

b Measured by XPS. 
$\mathrm{B}$, whereas the K species are probably well dispersed throughout the catalyst (Table 5).

\subsection{Roles of K and B modifications}

The modification of the Fe catalyst with an appropriate amount of $\mathrm{K}^{+}$significantly enhanced the conversion of $\mathrm{CO}_{2}$ (Tables 1 and 2). The selectivity for CO decreased, and that for hydrocarbons and organic oxygenates increased. This implies that not only the activation and conversion of $\mathrm{CO}_{2}$ but also the subsequent conversion of CO to hydrocarbons and organic oxygenates was accelerated by the modification with $\mathrm{K}^{+}$and other alkali metal ions because the hydrogenation of $\mathrm{CO}_{2}$ to hydrocarbons is believed to involve two steps, i.e., the RWGS reaction and subsequent $\mathrm{CO}$ hydrogenation. The enhanced $\mathrm{CO}_{2}$ chemisorption as a result of the presence of $\mathrm{K}^{+}$may be one of the reasons for the increase in the conversion of $\mathrm{CO}_{2}$. It is also possible that the adsorption of $\mathrm{CO}_{2}$ on $\mathrm{K}-, \mathrm{Rb}-$, or Cs-modified Fe catalysts with stronger basicities is easier than that on Li- or Na-modified Fe catalysts, and thus the first set of catalysts gave higher $\mathrm{CO}_{2}$ conversions.

However, it is well known that $\mathrm{K}^{+}$promotes activity in $\mathrm{CO}$ hydrogenation, i.e., FT synthesis [13]. Many studies have proposed an electronic promoting effect of $\mathrm{K}^{+}$[13]. The $\mathrm{K}$ may weaken the bonds of $\mathrm{CO}$ adsorbed on Fe by increasing the electronic density of Fe particles, which can then be back-donated to the anti-bonding orbital of $\mathrm{CO}$, leading to increased dissociation of CO. Strongly basic alkali metal ions, including $\mathrm{K}^{+}, \mathrm{Rb}^{+}$ and $\mathrm{Cs}^{+}$, may therefore function as electronic promoters for the enhancement of $\mathrm{CO}$ conversion; this is supported by the lower selectivity for CO over these modified catalysts (Table 1).

Our XRD results suggest that modification with $\mathrm{K}^{+}$enhances generation of the $\chi-\mathrm{Fe}_{5} \mathrm{C}_{2}$ phase during the reaction (Figs. 1 and 2). Many studies have proposed that the $\chi-\mathrm{Fe}_{5} \mathrm{C}_{2}$ phase is the active phase for FT synthesis over Fe-based catalysts $[22,25,26]$. Although the magnetite $\left(\mathrm{Fe}_{3} \mathrm{O}_{4}\right)$ phase, which was previously suggested to be the active phase in FT synthesis [14], was observed in all the catalysts, the low activity of the non-modified Fe catalyst in $\mathrm{CO}_{2}$ hydrogenation (Table 1) allowed us to exclude the possibility of $\mathrm{Fe}_{3} \mathrm{O}_{4}$ as the active phase. We therefore speculate that $\mathrm{K}^{+}$and other alkali metals accelerate $\mathrm{CO}$ conversion by accelerating formation of the $\chi-\mathrm{Fe}_{5} \mathrm{C}_{2}$ phase.

Furthermore, the product distribution in the hydrocarbon products was changed significantly by modification with $\mathrm{K}^{+}$or other alkali metal ions (Tables 1 and 2). The significant decreases in the selectivities for $\mathrm{CH}_{4}$ and $\mathrm{C}_{2}-\mathrm{C}_{4}$ paraffins, and the increases in those for $\mathrm{C}_{2}-\mathrm{C}_{4}$ olefins and $\mathrm{C}_{5}$ hydrocarbons (particularly $\mathrm{C}_{5+}$ olefins), clearly indicate that the hydrogenation ability decreases and the chain-growth ability increases in the presence of $\mathrm{K}^{+}$or other alkali metal ion modifiers. We speculate that the enhanced $\mathrm{CO}$ adsorption and dissociation ability in the presence of $\mathrm{K}^{+}$may lower the adsorption of $\mathrm{H}_{2}$ on the catalyst surface and thus decrease the hydrogenation ability.

Concerning the role of $\mathrm{B}$, the addition of a small amount of $\mathrm{B}$ to the 5 -wt $\%-\mathrm{K}^{+}$-modified $\mathrm{Fe}$ catalyst slightly increased the conversion of $\mathrm{CO}_{2}$, possibly because of the increased specific surface area. However, when the content of B became $\geq 3 \mathrm{wt} \%$, decreases in $\mathrm{CO}_{2}$ conversion were observed (Table 3). We speculate that this is caused by a decrease in the amount of $\mathrm{CO}_{2}$ chemisorption (Table 4) as a result of the acidic character of $\mathrm{B}$. It is interesting that modification of the $5-w t \%-\mathrm{K}^{+}$-modified Fe catalyst with B significantly suppressed the formation of $\mathrm{C}_{5+}$ hydrocarbons, but the selectivity for $\mathrm{CH}_{4}$ was not enhanced (Table 3). For example, the selectivity for $\mathrm{C}_{5+}$ hydrocarbons decreased from $30 \%$ to $19 \%$, whereas that for $\mathrm{C}_{2}-\mathrm{C}_{4}$ olefins increased from $34 \%$ to $40 \%$ after the addition of $1.0 \mathrm{wt} \% \mathrm{~B}$ to the $5 \mathrm{wt} \% \mathrm{~K}-\mathrm{Fe}$ catalyst. The selectivity for $\mathrm{C}_{2}-\mathrm{C}_{4}$ olefins further increased to $52 \%$ when the B content was increased to 3 wt $\%$, but the $\mathrm{CO}_{2}$ conversion decreased. In an early work, Li et al. [27] observed that the products shifted to lower-molecular-weight hydrocarbons, particularly $\mathrm{C}_{2}-\mathrm{C}_{4}$, on B-doping of a Co-based catalyst during FT synthesis. The increased fraction of cobalt oxide to metallic Co or the decreased reducibilities of the Co catalysts in the presence of B were suggested to be responsible for the change in product selectivity. In our case, we still do not have a satisfactory explanation for the role of $B$ in regulating the product selectivity. Future studies are needed to clarify the role of B.

\section{Conclusions}

The hydrogenation of $\mathrm{CO}_{2}$ to light $\left(\mathrm{C}_{2}-\mathrm{C}_{4}\right)$ olefins was studied over non-supported Fe catalysts. We found that modification of the Fe catalyst, which was prepared by calcining ammonium ferric citrate, with alkali metal ions significantly enhanced the conversion of $\mathrm{CO}_{2}$ and the selectivity for $\mathrm{C}_{2}-\mathrm{C}_{4}$ olefins. The selectivity for $\mathrm{C}_{5+}$ hydrocarbons, particularly $\mathrm{C}_{5+}$ olefins, was also enhanced by the addition of an alkali metal ion. The formation of $\mathrm{CH}_{4}$ and $\mathrm{C}_{2}-\mathrm{C}_{4}$ paraffins was largely suppressed. The fresh catalyst without modification contained iron oxide $\left(\mathrm{Fe}_{3} \mathrm{O}_{4}\right.$ and $\mathrm{Fe}_{2} \mathrm{O}_{3}$ ) phases, which were transformed into $\alpha$-Fe together with a small amount of $\mathrm{Fe}_{3} \mathrm{O}_{4}$ after reduction in $\mathrm{H}_{2}$ at $673 \mathrm{~K}$. This was also the case for the catalyst modified with an alkali metal ion, but the size of the iron oxide particles in the fresh catalyst was smaller after modification. After reaction under the specified reaction conditions, the formation of $\chi-\mathrm{Fe}_{5} \mathrm{C}_{2}$ occurred over the alkali-metal-ion-modified Fe catalysts, but iron carbide species were not observed in the unmodified catalyst after the reaction. The generation of iron carbide species in the presence of an alkali metal ion was proposed to be one reason for the enhanced catalytic performance. The increase in the amount of $\mathrm{CO}_{2}$ chemisorption as a result of the presence of $\mathrm{K}^{+}$ may also contribute to the increased $\mathrm{CO}_{2}$ conversion. The content of $\mathrm{K}^{+}$also affected the catalytic performance. If the $\mathrm{K}$ content was too high, this led to a decrease in the surface area and the amount of $\mathrm{CO}_{2}$ chemisorption and thus decreased the conversion of $\mathrm{CO}_{2}$. We found that the addition of a small amount of $\mathrm{B}$ to the K-modified Fe catalyst could suppress the formation of $\mathrm{C}_{5+}$ hydrocarbons and increase the selectivity for $\mathrm{C}_{2}-\mathrm{C}_{4}$ hydrocarbons, without significantly increasing the selectivity for $\mathrm{CH}_{4}$. With an appropriate B content, the selectivity for $\mathrm{C}_{2}-\mathrm{C}_{4}$ olefins reached $52 \%$. This provided another possibility for regulating the product distribution. 


\title{
Graphical Abstract
}

Chin. J. Catal., 2013, 34: 956-963 doi: 10.1016/S1872-2067(12)60559-2

Hydrogenation of carbon dioxide to light olefins over non-supported iron catalyst

YOU Zhenya, DENG Weiping, ZHANG Qinghong, WANG Ye*

Xiamen University

The modification of a non-supported Fe catalyst by alkali metal ions, particularly $\mathrm{K}^{+}$, in combination with a small amount of $\mathrm{B}$, significantly enhanced the hydrogenation of $\mathrm{CO}_{2}$ to light olefins.

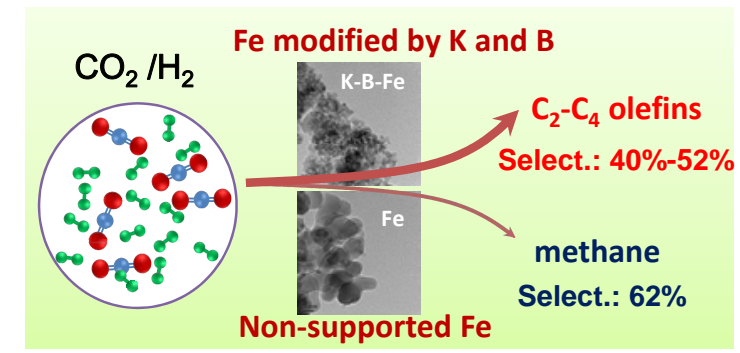

\section{References}

[1] Baiker A. Appl Organomet Chem, 2000, 14: 751

[2] Song C S. Catal Today, 2006, 115: 2

[3] Ma J, Sun N N, Zhang X L, Zhao N, Xiao F K, Wei W, Sun Y H. Catal Today, 2009, 148: 221

[4] Jin Zh L, Qian L, Lü G X. Prog Chem (靳治良, 钱玲, 吕功煊. 化学进 展), 2010, 22: 1102

[5] Wang W, Wang Sh P, Ma X B, Gong J L. Chem Soc Rev, 2011, 40: 3703

[6] Wang D J, Tao F R, Zhao H H, Song H L, Chou L J. Chin J Catal (王丹 君, 陶芙蓉, 赵华华, 宋焕玲, 丑凌军. 催化学报), 2011, 32: 1452

[7] Feyzi M, Hassankhani A.J Nat Gas Chem, 2011, 20: 677

[8] Lu J Y, Liu Y C, Li N. J Nat Gas Chem, 2011, 20: 423

[9] Prasad P S S, Bae J W, Jun K-W, Lee K- W. Catal Surv Asia, 2008, 12: 170

[10] Fujimoto K, Shikada T. Appl Catal, 1987, 31: 13

[11] Cubeiro M L, Valderrama G, Goldwasser M R, González-Jiménez F, da Silva M C, Pérez-Zurita M J. Stud Surf Sci Catal, 1997, 107: 231

[12] Riedel T, Schaub G, Jun K-W, Lee K-W. Ind Eng Chem Res, 2001, 40: 1355

[13] Zhang Q H, Kang J C, Wang Y. ChemCatChem, 2010, 2: 1030

[14] de Smit E, Weckhuysen B M. Chem Soc Rev, 2008, 37: 2758
[15] Choi P H, Jun K-W, Lee S-J, Choi M-J, Lee K-W. Catal Lett, 1996, 40: 115

[16] Dorner R W, Hardy D R, Williams F W, Willauer H D. Catal Commun, 2011, 15: 88

[17] Kim J-S, Lee S, Lee S-B, Choi M-J, Lee K-W. Catal Today, 2006, 115: 228

[18] Kishan M, Lee M-W, Nam S-S, Choi M-J, Lee K-W. Catal Lett, 1998, 56: 215

[19] Lee S-C, Jang J-H, Lee B-Y, Kang M-C, Kang M, Choung S-J. Appl Catal A, 2003, 253: 293

[20] Xu L-Y, Wang Q X, Liang D B, Wang X, Lin L W, Cui W, Xu Y D. Appl Catal A, 1998, 173: 19

[21] Herranz T, Rojas S, Pérez-Alonso F J, Ojeda M, Terreros P, Fierro J L G. Appl Catal A, 2006, 311: 66

[22] Yang C, Zhao H B, Hou Y L, Ma D. J Am Chem Soc, 2012, 134: 15814

[23] Dorner R W, Hardy D R, Williams F W, Willauer H D. Appl Catal A, 2010, 373: 112

[24] Brainard W A, Wheeler D R. J Vac Sci Technol, 1978, 15: 1800

[25] Yu G B, Sun B, Pei Y, Xie S H, Yan S R, Qiao M H, Fan K N, Zhang XX, Zong B N.J Am Chem Soc, 2010, 132: 935

[26] de Smit E, Cinquini F, Beale A M, Safonova O V, van Beek W, Sautet P, Weckhuysen B M. J Am Chem Soc, 2010, 132: 14928

[27] Li J, Coville N J. Appl Catal A, 1999, 181: 201

\section{非负载型铁催化剂上二氧化碳加氢制低碳烯烃}

\author{
游震亚, 邓卫平，张庆红，王 野*
}

厦门大学化学化工学院, 固体表面物理化学国家重点实验室, 醇醚酯化工清洁生产国家工程实验室, 福建厦门361005

摘要: 研究了非负载型铁催化剂上 $\mathrm{CO}_{2}$ 加氢制低碳烯烃反应. 结果显示, 添加碱金属可显著提高铁催化剂上的 $\mathrm{CO}_{2}$ 转化率和烯烃 选择性. 在经 $\mathrm{K}$ 和 $\mathrm{Rb}$ 修饰的 $\mathrm{Fe}$ 催化剂上, $\mathrm{CO}_{2}$ 转化率可达约 $40 \%$, 烯烃选择性达到 $50 \%$ 以上, 其中 $\mathrm{C}_{2} \sim \mathrm{C}_{4}$ 烯烃收率超过 $10 \%$. 催化剂 表征结果表明, 碱金属促进了催化剂中碳化铁的生成, 这可能是催化剂性能提高的一个关键原因. 随着K含量由 $1 \mathrm{wt} \%$ 增加至5 wt $\%, \mathrm{CO}_{2}$ 转化率及烯烃选择性均升高. 但 $\mathrm{K}$ 含量过高时, 催化剂活性降低. 这可能是由于催化剂比表面积和 $\mathrm{CO}_{2}$ 化学吸附量降低 所致. 当 $\mathrm{K}$ 含量为 $5 \%$ $10 \%$ 时, $\mathrm{K}-\mathrm{Fe}$ 催化剂上烯烃收率较高; 进一步添加适量的硽可进一步提高烯烃选择性, 且 $\mathrm{CO}_{2}$ 转化率下降不 大.

关键词: 二氧化碳; 加氢反应; 低碳烯烃; 铁催化剂

收稿日期: 2013-01-12. 接受日期: 2013-02-21. 出版日期: 2013-05-20.

*通讯联系人. 电话: (0592)2186156; 传真: (0592)2183047; 电子信箱: wangye@xmu.edu.cn

基金来源：国家重点基础研究发展计划(973计划，2013CB933100); 国家自然科学基金(21173174，20923004，21033006, 21161130522); 高等学校博士学科点专项科研基金(20090121110007); 教育部创新团队发展计划(IRT1036).

本文的英文电子版由Elsevier出版社在ScienceDirect上出版(http://www.sciencedirect.com/science/journal/18722067). 